\title{
The incantations of the EU organised crime policy making
}

\author{
P. C. van Duyne - T. Vander Beken
}

Published online: 11 October 2008

(C) Springer Science + Business Media B.V. 2008

\begin{abstract}
This article provides an analysis of the knowledge base of organised crime assessments and policy making in the European Union. It is argued that the current European organised crime (threat) assessments are no reliable and relevant instruments to make meaningful statements about organised crime. The data collection system of the current assessments is defective and to a large extent dependant on what Member States decide to disclose and not based on clear developed concepts, definitions and methods. There is no discernable "counting unit" as a basis for deducing threats or risks. More fundamental: the definition or criteria list used is defective, providing no basis for further deductions or conclusions. The conclusions of the open versions of the European reports are of a very general nature, not substantially different from what can be found in open sources. Though European decision making claims to be founded on these assessments, it looks more like a ritual incantation than a knowledge based process.
\end{abstract}

\section{Rationality, fear and policy making}

It is a shared belief that modern western societies owe their 'rational' tradition to cultural mainstreams like the Enlightenment or even more ancient rational predecessors. Within this tradition, decision making, particularly concerning the public domain, should be rational too. However, the frequency with which this rationality principle is referred to may be taken as an indication that human and political life does not follow the narrow and enlightened path of rationality. Therefore, the present-day version of this evocation of rationality, namely 'evidence' or 'knowledge based policy making' should arouse

P. C. van Duyne $(\square)$

Empirical Penal Science, Tilburg University, Tilburg, The Netherlands e-mail: Petrus@uvt.nl

T. Vander Beken

Institute for International Research on Criminal Policy, Ghent University, Ghent, Belgium 
some suspicion. After all, looking back at present-day and historical policy making, the examples of 'knowledge denied' policy making may very well exceed the ones that were really knowledge based. Examples of current 'knowledge denied' policy making range from the Iraq tragedy to the AIDS drama in Southern Africa or the long denial of the global heating evidence by the US. Granted, the proponents of such knowledge denied policies emphasized that these were knowledge based too, though events proved them wrong.

Perhaps it is more plausible to argue that this rationality principle is a kind of public 'mental super-ego', surrounded by a lot of emotions, values, make-belief and plain self-interests, which come to the fore as soon as they get connected to perceptions of threats and related fears. To the degree that a policy area is leavened with emotions, values and threats, the invocation of the 'knowledge based policy making' should be scrutinised with commensurate care. What does it really mean, why is it invoked and with what intension: as a ritual or as a serious wish for obtaining insight?

Unmistakably, criminal policy making is such a policy area: emotions soon run high while the threat component is always present. For this reason, the motto 'knowledge based policy making' deserves a closer look indeed. This is particularly relevant concerning themes that score high on the emotion and fear component. One of those fearful themes, which captured political attention for more than two decades, is 'organised crime'. From its beginning this proved to be a fear and threat leavened topic. It is also a topic with numerous stakeholders nationally and internationally, ranging from the plain detective to high-level policy makers. The interests at stake concern penal (international) legislation as well as budgets. To say that against the background of so many interests the stakeholders would act irrationally because of the fearful nature of the topic, would seriously underestimate them. The ways this political subject has been managed reflects at any rate a rational 'fear management' [60, 20]. But has this been based on the foundations of knowledge about the phenomenon of 'organised crime' itself? And if policy makers aimed to do so, what was the assumed nature of this knowledge and how well-based and valid was it? If these questions have to be answered negatively, we may have to address another question: whether and to what extent the "knowledge based policy making' motto is just a social gesture with words, a ritual incantation after all.

\section{Organising the organised crime threat}

Though crime has always been a 'natural' accompanying phenomenon of the regulation of societal interests, 'organised crime' is not such a 'natural phenomenon'. As a matter of fact, the history of the awareness of organised crime, in the US [39] as well as in Europe shows that there is little natural about this 'phenomenon'. But is it a phenomenon in the first place? That is quite uncertain. Can it be observed like other criminal phenomena, such as (the results of) a burglary, a forged banknote, a container with hidden, untaxed cigarettes? No, it cannot. Nevertheless, when we look at the whole discourse of 'organised crime', the language used, the denotations, 'organised crime' has become a real, personified phenomenon in the eyes of many beholders. Not only in the media, but also in policy papers one finds phrases like "organised crime is on the march"; "it increases and threatens" [18, 58]. Whether it 
is a real phenomenon does not matter as long as it is perceived as such and presented as such in the appropriate langue. To paraphrase the English philosopher of language Austin, language not only reflects, but can create reality [1].

Though it has been declared a criminal phenomenon, the nature and extent of which was still unknown, it was not a self-explanatory political issue. While some hazy concept of 'organised crime' was generally known (mainly from the entertainment industry), in the late 1980s, many Western European politicians did not think it a real problem in their own country. Hence, if the law enforcement agencies wanted to move this issue up on the policy agenda, a public awareness policy had to be worked out. A proper entry is the always present concern of serious crime. Of course, most countries have various forms of serious crimes (for profit), and it is understandable that these were to be subsumed under the denominator 'organised crime'. Whether that really fitted analytically was of less concern: these two words could at any rate be given some content by association. Indeed, in most policy papers one finds from the very beginning of organised crime policy making the phrase 'serious and organised crime'. In this way one cannot go wrong: organised crime is always serious.

Political awareness campaigns are not very special and hardly differentiate from a commercial undertaking of introducing a new brand into the market. Awareness raising, like promoting a brand popularity, has to be organised. In the first place it must evoke emotion. Raising awareness without emotion is doomed to fail. This may be one of the reasons of the success of OC awareness raising compared to similar attempts of the EU Commission concerning crime against the EU financial interests. For more than 20 years the Commission has tried to make policy makers, law enforcement agencies and the public aware of the seriousness of 'EU-fraud'. All to no avail. Of course, the member states did not obstruct and duly complied with the demands from 'Brussels', also the new Member States [51]. But even in times of Enron [53] and financial scandals in Europe (see e.g. [5]) EU-fraud (or other forms of economic crime) never became really 'hot'. Public and political interest for fraud has always been subjected to pendulum motions.

However, raising the awareness of an elusive phenomenon, even under the banner of a clear colloquial name (hence everybody thinks he knows what it is about), did not develop along a smooth and even path. It was also not 'European synchronised'. Some Member States were already very much aware of an 'organised crime' threat, others took some time to discover it. But they all discovered 'their' organised crime 'problem'. Which Member State could afford stating not to have an organised crime problem while participating in relevant working groups?

\section{The making of the $\mathrm{OC}$ concern in member states}

The phrase 'organised crime' is not an outlandish string of words. For decades, popular movies and books disseminated a generally and intuitively understandable image of what it might be. Attention was also paid to the US, where the concern about organised crime did not go unnoticed in Europe. Questions were raised (or rather statements were made) in various countries: do we have (such) an organised crime problem too? Italy did not need to raise that question: it has its own 'organised 
crime' problem in the form of the ineradicable Sicilian mafia since the late 19th century. ${ }^{1}$ In other countries many were uncertain to answer this question affirmatively. All in all, though the organised crime image was fascinating and entertaining, until about the 1980 s, its characteristics were still considered typical American (or Italian). And: 'we are not like America' (or Italy, which was considered even more unlikely).

This does not imply that the authorities were free of criminal concerns. During the 1970s, the drug market expanded rapidly [23], while cases of serious professional property crime received repeatedly attention [54]. No one denied the existence of criminal professionals operating in the 'traditional' underworld of local thugs and hoodlums [45], later accompanied by new ethnic minority crime-entrepreneurs. These old concerns of 'serious' crime would become remoulded into an 'organised crime' conceptualisation and a related concern as indicated in the previous section.

In Germany and the Netherlands the enfolding of an organised crime concern could be observed during the beginning 1980s. In that regard, these two countries were ahead of the other EU member states, with the exception of Italy. At first warnings about a looming threat hardly struck a chord. As time went by, the interaction between diligent problem owners, national and local politics, the media and the exploits of major crime-entrepreneurs on the drug market and red-light districts, brought the organised crime issue prominent to the fore, also in the UK after 1993. Let us have a brief look at these countries.

\section{Germany}

In Europe, Germany is probably the first country in which the awareness of organised crime as a social problem gained momentum. Subsequent to the publicity peak in the United States in the 1960s, among others caused by the Vallachi testimonies in 1963, the phrase 'organised crime' was introduced in Germany. From this very beginning, which primarily concerned German journalistic reports on organised crime as an American problem, it took about 20 years for organised crime to 'move to the centre of the German criminal policy debate' [38, 40]. Von Lampe measured peaks in 1975, 1989 and 1993. The awareness of German organised crime had its start in several future scenario's in which organised crime, perceived in a way similar to the American model, might become a threat to German society in the future.

In the early 1970s, the discussion had a twist. Concluding that the American Mafia paradigm did not correspond to whatever crime manifestations in Germany occurred or would occur, the German police officers re-coined 'organised crime' (Organisierte Kriminalität), thus preserving the phrase while changing its content [40]. In 1974, a commission formed by state and federal police agencies issued a first definition of organized crime. ${ }^{2}$ However, it did not end the conceptual discussion in Germany as intended. In fact it did not gain much influence altogether,

\footnotetext{
${ }^{1}$ However, even in Italy, the public debate on organised crime was fuelled by the Kefauver hearings.

2 "Organised crime comprises criminal acts that are committed by either combinations with more than two hierarchical levels or by several groups in a division of labour with the aim of obtaining profits or influence in public life" (Fachkommission "Organisierte Kriminalität" 1974, [40]).
} 
because the Bavarian Police, fearing a loss of power vis à vis the federal level, effectively vetoed the official acceptance of the definition [40].

In the following years the attention of organised crime faded, only to make a come-back in the 1980s [43]. A new joint state and federal committee was formed, based on the agreed opinion that serious forms of crime did pose a (future) threat to German society. A new definition was issued in 1983, reflecting a shift from a focus on hierarchical organisation to a networks approach. ${ }^{3}$ The focus on organised crime as a domestic phenomenon concerned mostly its purported manifestations in Germany's largest cities: the red-light zones ('Rotlichtmilieu') [3, 37].

In the following period the attention for organised crime gradually shifted from this network notion to (again) a notion based on the Mafia and syndicate paradigm. This time syndicates as a form of organised crime were considered a real threat. Nevertheless, Mafia-like activities were still primarily attributed to foreign criminal groups expanding their sphere of action to Germany. In 1990 a new definition was finally formulated by the Bundeskriminalamt which was soon included in the guidelines for criminal procedure: "Organised crime is the planned violation of the law for profit or to acquire power, which offences are each, or together, of major significance, and are carried out by more than two participants who cooperate within a division of labour for a long or undetermined time span using (a) commercial or commercial-like structures, or (b) violence or other means of intimidation, or (c) influence on politics, media, public administration, justice or legitimate economy" [37]. Beginning in 1992, the Bundeskriminalamt issued a yearly report on the 'organised crime' related investigations by state and federal police agencies. In the same year, the German Parliament passed the Act on Fighting Organised Crime (Gesetz zur Bekämpfung der organisierten Kriminalität, OrgKG) which provided the police with broader competencies. It may be doubted whether at that time this new awareness of the OC threat was really based on sound 'evidence' of the existence of organised crime [35, 43]. Existing research (all based on the rather weak 'Delphy-method') pointed in the direction of crime-entrepreneurs operating in networks $[52,63]$.

\section{The Netherlands}

In the Netherlands, the development of the political concern for organised crime developed somewhat later than in Germany. There were various tributaries, which as time went by flowed one into the other to become an uncontrollable torrent in the end. An ensuing scandal proved to have a major impact.

Within the Ministry of Justice, the attention for organised crime started ironically as a by-product of a 1985 policy paper on frequently occurring petty crime, which contained one small section about the need to remain alert to wholesale drug trade. This section, being inserted by the minister himself, reflected concern as well as pragmatism. Allegedly, the Minister broadened the span of attention with a future

\footnotetext{
${ }^{3}$ The definition was: "A conscious and willing, continuous cooperation in a division of labour between several persons for the purpose of committing criminal acts - frequently with the exploitation of modern infrastructure-with the aim of achieving high financial gain as quickly as possible" (Ad hoc-Ausschuss 1983, [40]).
} 
agenda item, realising that he may need it later when the political attention in the Second Chamber had to be boosted again. Another furtherer of the organised crime attention was Cyrille Fijnaut, who had studied the organised crime situation in New York and warned against the looming threat of new forms of organised crime in the Netherlands, which for want of proper studies police impressions had to be based on police impressions [29]. A third booster was the Amsterdam police, which had to deal with violent commercial crime-entrepreneurs: Turkish heroin importers and Dutch hashish wholesalers who defended their turf with guns and bombs, leaving a score of victims on the streets [46]. Finally, and lending authority to the organised crime portfolio, there was the Prosecutor General of the Southern Public Prosecution Office, Gonsalves. He was a crime-fighter pure sang and was confronted with violent criminal gangs from trailer camps in Brabant and Limburg, shooting their way into and out of their targets [22]. Gonsalves got his way and 1987 became chairman of the 'task group Gonsalves' for 'serious and organised crime'.

Gonsalves established another task group 'Crime Analysis' for making a quantitative assessment of the organised crime situation. This task group duly produced a questionnaire, reported on the responses in 1988, but in the wording it created the impression that the number of the 189 returned forms equated the number of criminal organisations. As a matter of fact, Gonsalves had the report leaked to the press, to the dismay of his senior staff who thought it unethical to let methodologically flimsy findings come into the open [20]. ${ }^{4}$ Three years later the task group Crime Analysis carried out another review with a similar methodology and public relation policy: making it classified and leaking at the same time. Irrespective of the 'evidence based' (in)validity, such initiatives - the outcomes of which were rarely questioned - contributed strongly in upholding political awareness. ${ }^{5}$

The police commissioners of the big cities like Amsterdam and Rotterdam had little interest in such subtleties. Their concerns were the few 'untouchable' Mr. Bigs, which implied an emphasis on serious ('heavy') and organised crime. This led to the inclusion of usually violent groups, which may not represent organised crime at all, at least according to the standards adopted by the task group Crime Analysis. ${ }^{6}$ To bring one such "Mr Bigs" down, large detective units were established. This traditional approach was fanned by Fijnaut in the 'Dutch-American Conference on Organised Crime' in 1990, an event proclaimed a 'watershed' in the way of thinking about organised crime [30, 31], but before as well as after this 'watershed' this thinking remained unclear. There was no observable sharpening of the conceptual framework of 'organised crime'. There was just a consensus that it concerned a serious and threatening matter.

\footnotetext{
${ }^{4}$ In an internal memo 'Organisational mishap' (March 1996) one of the analysts of the working group expressed his annoyance with the applied methodology and the way concepts of organised crime and criminal groups were mixed resulting in the inclusion of more cases. Nothing was done with this observation.

${ }^{5}$ This policy of misinformation was later admitted by the Utrecht Chief Commissioner, Utrecht Nieuwsblad, 16 December 1992 [20].

${ }^{6}$ This task group did not consider so-called 'group criminality' as organised crime, however, according to the memo referred to in the previous footnote, they were nevertheless included in the results of the questionnaire.
} 
After 1990, the concern about organised crime at the level of important police and public prosecution managers, policy makers and politicians, was firmly established [20]. These worries did not only concern the evil deeds of 'organised' thugs and hoodlums, they also concerned the feared penetration of the 'upperworld' because of the alleged huge criminal revenues. This threat was also widely proclaimed by the Financial Action Task Force on Money-laundering, whose (gu)estimates of the amount of crime-money and the laundering thereof were generally accepted without much debate [23, 42]. In general, the state of concern, sometimes expressed excitedly, did not contribute to any open debate. There was rather an (unquestioned) demand for tougher action. During the debate in the Second Chamber (1992) the politicians outbid each other and the minister of Justice in their display of concern: 'Organised crime is on the march' etc., much to the dismay of one of the moderate representatives, later to become minister of Justice [50, 20].

Within this heated climate, the Organised Crime Strike Force experimented with shady investigative methods: allowing a criminal informant to import thousands of kilos hashish and cocaine (without intercepting) in order to come closer to the 'highest command level' of organised crime. The secret plan came into the open and caused a tremendous scandal. In its wake, the ministers of Interior and Justice resigned and a Parliamentary Investigative Commission was established to investigate police methods. On behalf of this Commission, a research team would carry out an organised crime assessment, as by now the first assessments by the task group Crime Analysis were considered unsatisfactory. The Commission itself assumed the task of investigating the appropriateness of the contested investigative methods.

\section{United Kingdom}

The first United Kingdom recorded demonstration of organised crime awareness was the Organised Crime Conference: a Threat Assessment in 1993 in the Police Staff College. The first sentence of the introduction adequately illustrated the level and accuracy of the awareness: "Organised crime has many definitions; this may be because it is like an elephant-it is difficult to describe but you know it when you see it" [48]. Apparently that was clear enough at that time.

Subsequently NCIS issued a briefing paper "An outline assessment of the threat and impact by organised/enterprise crime upon United Kingdom interests" (1993). The assessment warned in no uncertain terms that, "behind the words in this paper lurk some of the most brutal international criminals ever known". NCIS warns that the scale of the problem exceeds the reported cases because of underreporting (among others by financial institutions), but states that intelligence suggests thatthough probably more fragmented than elsewhere - the problem is probably similar to that found in some other EU Member States. ${ }^{7}$ The briefing paper sums up crime themes with an 'organised crime potential', and in addition describes threatening criminal groups, mainly foreign (bikers excepted). The report is very economic in describing their actual criminal activities in the UK [47].

\footnotetext{
${ }^{7}$ At that time only the Netherlands and Germany had an organised crime situation report.
} 
In March, May and June 1994, the Home Affairs Committee held hearings to obtain an overview of organised crime based on expert witnesses and memoranda. In the discussions in the Committee and with the expert witnesses two issues attract the attention [34].

The first issue concerned the uncertainty about the definition. The chairman, Sir Ivan Lawrence, was of the opinion that "precise definitions of organised crime are (a) not very possible and (b) not very useful. It therefore follows that it is very difficult to estimate the extent..." The document reflects much circular reasoning concerning serious and organised crime: organised crime concerns serious crime, because serious crime is always planned.

Further, there was a discussion about foreign and indigenous organised criminals, to which witnesses referred frequently. In the end, one of the committee members asked specifically whether there are "any domestic home grown United Kingdom properly organised criminal gangs". The witness "regretfully" admitted that the UK "has a wealth of talent in that regard.... [of] networks of career criminals". Among these, there was not just one Mr. Big, but many. Nevertheless, in the minutes of the Home Affairs Committee (1994) the foreign criminal element was preponderant in the testimonies, mainly connected to drug trafficking.

Other countries followed suit in the 'discovery' of their organised crime, which apparently had been slumbering unnoticed for many years. Or were they prompted by the fact that the topic has been put on the EU agenda? As often happens, after the agenda has been set and if there are no strong political counter arguments, Member States' delegates tend to join the choir. Thus, from 1993, Europe had a politically certified organised crime problem, irrespective of the circumstance that neither anyone knew what it actually was, but 'recognized it as soon as one saw it', or everybody had a different picture of what this 'phenomenon' was supposed to be. This implies that the knowledge base was extremely questionable. What was the actual knowledge base at that time? In short: a confused conceptualisation, a multitude of definitions and impressionistic observations.

Organised crime and its assessment on the European agenda: the OCSR

Given the previous description, it is difficult to talk of $a$ 'European' organised crime concern, because justice and law enforcement are (still) matters of national sovereignty, certainly at the time when the organised crime concern was taking root. ${ }^{8}$ Nevertheless, there are many criminal justice problems, which are shared by all European countries. For example, the increasing cross-border drug trafficking was considered an organised crime matter [23]. ${ }^{9}$ As far as the European Commission was concerned, (organised) fraud against the European public funds was a matter of highest concern, though the member states did not respond with the same sense of urgency. To sketch the awareness situation around 1990: there was a certain awareness of an organised crime problem, particularly related to drug trafficking, but

\footnotetext{
${ }^{8}$ Except for the episodic cross-national study commissioned by the Council of Europe [44].

${ }^{9}$ The interception frequencies of all brands of psychoactive substances increased significantly after 1985, while the prices gradually went down $[26,49,23]$.
} 
there was not an officially proclaimed concern yet, as was to be observed in Germany, the Netherlands and Italy at that time.

In 1992, events in Italy changed the agenda considerably. The on-going mafia war around 1990 attracted already international media attention, but was still considered a far-away gruesome (and exiting) Italian affair. The murders of the judges Falcone and Borsellino in the summer of that year evoked much concern all over Europe. The question was raised what would such a powerful Mafia do when the border controls between the Schengen-countries were abolished? Would they 'cross the Alps' (in the reverse direction of Hannibal and Napoleon) and stretch 'their tentacles' all over Europe? In regard to this perceived threat the Italian and French Ministers of Justice convened a special European meeting of their colleagues in September 1992. At the time not all Member States were equally convinced of the existence of a European problem. The haste and poor preparation of that meeting reinforced the feeling of the wary British chairman that it was just a political ritual gesture [18]. Nevertheless, the organised crime problem was from that time onwards indelibly on the political law enforcement agenda. The Maastricht Treaty on European Union of 7 February 1992 set up Europol which started in 1994 in the form of the Europol Drugs Unit (EDU) fighting against drugs, progressively adding other important areas of criminality.

In November 1993, the European Council decided that an annual strategic report on organised crime was to be issued. The aim of this report would be to provide insight into the organised crime phenomenon within the European Union. In November 1994, the Council accepted the production of this Organised Crime Situation Report (OCSR) to be dependent upon the exchange and analysis of information by the Member States. It was therefore agreed to set up a common mechanism for the systematic collection and analysis of information. This mechanism was used for the 1994 and 1995 EU situation reports. However, this mechanism did not amount to much more than the putting together of the national organised crime situation reports. Though each Member State was to provide a description of their methodology used, few honoured this request or in such a wording, that it hardly deserves the qualification of 'methodology'.

In 1997, the basic 'methodology' was further developed (Enfopol 35) and the new methodology was applied for the first time in the 1997 report. This methodology was based on a set of criteria, containing four mandatory and seven optional features. A crime group had to fulfil the four mandatory and two optional features to be qualified as 'organised'.

Like many definitions, these Enfopol criteria, though discussed on various occasions later, (but still used for OC assessments) have been subject to critique: most components of the definition can be considered ambiguous, badly delineated, redundant or overlapping with other components [17, 19].

In the meantime, the European Council in Dublin-13 and 14 December 1996and irrespective of what was known about it, underlined its absolute determination to fight 'organised crime'. It stressed the need for a coherent and coordinated approach by the European Union and decided to create a High Level Group on Organised Crime tasked with drawing up a comprehensive Action Plan containing specific recommendations, including realistic timetables. The work of the High Level Group resulted in the Action Plan of 28 April 1997 to Combat Organised Crime. This 
Action Plan set up a Multidisciplinary Group (MDG) on organised crime which was intended especially to comprise judicial authorities and police representatives and to stimulate an integrated approach to combat organised crime [6]. A Contact and Support Network (CSN) was established to examine the issue of the measurement of organised crime. Actually, the 'action plan' did little else than creating some formal structures for communication and meetings of civil servants of the Member States.

Tasked with the further development of the methodology and involved in the production of the EU Organised Crime Situation Report, the purpose of the network was to ensure the quality of the reporting process and of the report's content. In February 1999-under the German Presidency-the discussion was resumed on improving the methodology. A document was produced, proposing three steps towards a further development of the European OCSR. These steps, which were intended to provide a long-term perspective, were the following [7]:

- a generally recognised data collection mechanism and a uniform collection of certain basic data in all member states (which would contribute to the harmonization and standardisation of the reports);

- the collection of qualitative data/material to furnish a more exact and detailed description of organised crime;

- the use of a threat assessment methodology describing the conditions that foster crime, as well as the causes of organised crime.

This document did not initially give rise to a specific action on the issues proposed. The requirement of a standardisation of the data collection was acknowledged, but a follow-up to operationalise this condition was not made. Likewise, the recommendations about qualitative data and a threat methodology remained in quite general terms. Granted, the documents expressed a desire to develop a 'knowledge based' policy making, but they did not go further than an incantation of 'knowledge' with no elaboration of the specific conditions this had to meet or a justification of its foundations. There was an expressed concern of organised crime, being a reflection of that of the Member States, but otherwise it is difficult to detect a real sense of urgency or a realisation that this concern must be based on solid knowledge. Nevertheless, while the latter was not yet resolved the German presidency made a first move towards something new, subsequently picked up by the Swedes: a threat assessment.

\section{Towards a threat assessment}

In 1999 and 2000, the Swedish delegation prepared by the Belgian presidency made a following move and announced the intention of Europol and the MDG to change the structure and composition of the OCSR. According to these ideas, the focus of the report should shift from the description of current and past situations to assessment of threats and risks related to future developments in (organised) crime and their implications for law enforcement within the EU. It was therefore proposed that the organised crime situation report should be an annual strategic report produced for the purpose of planning, within the EU and the Member States, by the Police Chiefs Task Force (PCTF) and Europol. The aim of the proposal was to make 
the purpose of the report clearer to its users so that it would facilitate the collection of national contributions and provide a better foundation for the formulation of conclusions in the overall EU report, which would result in better and clearer recommendations [8].

Based on this, Europol examined its OCSR and decided to re-orient the reports to a threat assessment based on OCSR and emerging phenomena. According to Europol, an overview of this kind would be complementary to those produced by the Member States. If the Member State reports became more threat or future oriented, Europol stated, the two mechanisms would support each other to produce an even better overview of the situation in the EU, and the result would be a vital document for prioritisation, planning and common action within the EU.

On March 13, 2001 the Commission services and Europol issued a Joint Report entitled 'Towards a European Strategy to Prevent Organised Crime' [9] which (based on discussions with Member States) proposed the development of an information collection plan reflecting a knowledge-management process from a multidisciplinary perspective. In line with the prior proposals, the Joint Report proposed that explanatory annual reports should be compiled, rather than the traditional descriptive documents. What the contents of this knowledge management was supposed to remain unspecified: the report does not go beyond a 'word-formula'.

Later in 2001 the CSN discussed a possible change to the structure of the EU OCSR and recommended to the Multidisciplinary Group that the OCSR should be converted into an annual strategic report. Such a strategic report would be used for planning purposes, and it would focus on assessment of relevant threats and risks as well as on recommendations related to combating and preventing organised crime. As a consequence of this shift to a more future-oriented report, it was recommended that the name of the OCSR should be changed. The report should no longer be called a 'situation report' as it was to have a three-year perspective, should have annexes describing new trends and tendencies, and put forward stronger recommendations to its recipients. Consequently, it would simply be called the Organised Crime Report, OCR.

In short, the OCSR should become more threat, trend, assessment, and future oriented with a perspective of three years; it should use appendices so that it became a timely product, and it should become more 'customer' oriented by allowing the Heads of the National Units (HENUs), the PCTF and other decision-makers to have their say in its overall structure and orientation [61]. Did the texts stipulate or describe in detail what this future oriented perspective of the annual report with all its customer oriented addendums was to look like? No.

In the autumn of 2001, the Belgian Presidency proposed an action plan to convert the OCSR into an annual strategic report for planning purposes with the primary focus on assessment of relevant threats and risks, as well as on recommendations related to combating and preventing organised crime [10]. The basis was to be a conceptual model, discussed in formal and informal CSN meetings and proposed by the Belgian Presidency, which comprised the analysis of traditional and nontraditional elements: environmental analysis, organised crime group analysis, analysis of counter measures developed by criminal organisations, as well as scans of the legal and illegal markets. Attached to this action plan was a first inventory of the existing approaches and methodological tools, as well as a time schedule for the 
plan. The aim of the action plan was to determine and schedule a number of measures required to study various aspects of organised crime. As a general rule, the new methodological approach would be adopted in the following stages:

- identification of sources by consensus;

- consideration of a threat and risk assessment model and agreement on a general model;

- agreement on carrying out an analysis of the topic identified and production of a first revised report;

- feedback from customers on the first report, revision, evaluation and recommendations for future development [61].

This action plan was ambitious even it was intended to be executed over several years. Though without proper references, it supposedly reflected research on risk based methodologies for the measurement of organised crime $[2,56]$. But it had the weakness that it focused on the use of the information that was gathered in order to define organised crime risks and threats to the European society, while it left the methodological problems related to the basic underlying data collection unaddressed. In addition, the action plan only developed a model without elaborating all terms and concepts of this new approach. In short, though models do influence information needs, the action plan was considered to take the second step first [41] by jumping into threat assessment methodologies before a solid and reliable information base was developed.

In 2004, the The Hague Programme [11], built upon the progress and experience of the former 5 years and reaffirmed the importance of an area of freedom, security and justice as a high priority on the EU-agenda. This programme states that Europol must replace the crime situation reports by yearly threat assessments on serious forms of organised crime, which will be used by the Council to establish yearly strategic priorities. These, in turn, will serve as guidelines for further action and will be the next step towards the goal of setting up and implementing a methodology for intelligence-led law enforcement at EU level. The Hague Programme explicitly calls again for a forward looking approach to fight organised crime in a more pro-active than in a re-active manner.

In order to efficiently execute the Hague Programme, the Commission identified 10 priorities on which it felt efforts should be concentrated, one of them being the 'developing of a strategic concept on tackling organised crime' [25]. On 2 June 2005, a more specific communication about 'developing a strategic concept on tackling organised crime' was made [12, 24], pleading for the development of a European Criminal Intelligence Model (ECIM) of which a European OC threat assessment (OCTA) by Europol should be the key element. How that should be implemented has never been clarified.

On 3 October 2005, the Council concluded that from 1 January 2006 onwards, Europol was to produce an Organised Crime Threat Assessment (OCTA) in place of its annual Organised Crime Situation Reports [13], in order to support the further development of a common intelligence model, by Europol and the Member States.

In 2006, the first OCTA was presented [27] and in 2007 the second [28]. The assessments lead to policy conclusions drafted by the Council of the European Union in 2006 and 2007 [14, 15]. The next chapter takes a closer look at these 
OCTA reports and the policy conclusions taken by the Council based on these assessments in order to get an understanding of the knowledge base of the current organised crime policy making in the EU.

\section{The OCTA: a threat assessment?}

The OCTA has the clear ambition to be used in an intelligence cycle to feed the European decision making processes in the fight against organised crime. The OCTA does not aim to provide figures and numbers of criminal groups, but qualitative and forward looking statements (knowledge) about the challenges this phenomenon poses: "The OCTA marks a new approach to the way in which Europol and the Member States will think and operate in the future and it is a first step to change of paradigm in policing. The OCTA fits in firmly with the aim of "The Hague Programme" to provide a forward looking approach to fight organised crime in a more pro-active than reactive manner. It is complemented by the development and implementation of the European Criminal Intelligence Model (ECIM). The OCTA allows the EU to develop complementary measures to countering organised crime, linking those at the ministerial and political levels with those of practitioners and law enforcement agencies who operate at the front line." [28]

The OCTA explicitly claims to be a threat assessment. Although many definitions and ideas about the definition of 'threat' exist and are used, it does fit in a larger conceptual risk assessment framework. Risk can be broadly defined as the chance of something happening that will have an impact on objectives. It is measured in terms of likelihood and consequences [2] - see also [16]. However, risk as a working concept is defined depending on the agency and its requirements. For some agencies, risk definitions coalesce around the likelihood and impact of loss, injury, disadvantage or destruction or exposure to hazard or danger. For others, in more neutral mode, risk definitions focus on the chance of something-positive and/or negative - happening that will have an impact on objectives. Those agencies tasked with the responsibility of public and national security (i.e., those that act in a protective capacity) generally rely on the negative aspect of impact, and thus the likelihood of events or actions (which they then define in terms of threat) is often the defining variable [56]. The main focus of threat assessments is on the intent and capability of the criminal actors involved (further operationalised by specific indicators. See on this e.g. [4, 55], not on the consequences (impact, harm) this might cause (impact assessments). It is also possible, apart from threat and/or impact, to study the vulnerability of the (legal) environment of ('organised') crime and assess to what extent capable and willing offenders (threat) have the opportunity to commit their acts and cause harm to society (impact). Given the profit driven nature of organised crime, vulnerability studies in organised crime assessments should address the vulnerability of economic sectors (e.g. transport, waste disposal, see [57].

Even if these ambiguities could be resolved, there is a fundamental flaw: none of the terms being used has an operationalised, unambiguous content. Such an operationalisation would be the logical step following the studies of Ghent University. However, in the OCTA-6 document there is no indication that such a 
step was even considered. More fundamental, the concept of chance or likelihood remains without operationalisation too as no numerical parameter has been specified: likelihood is $\mathrm{x} / \mathrm{N}$. Such specification is of course impossible as long as there is no definition of the relevant counting unit(s). This hinges again on the defective organised crime definition which is incapable of delineating counting units. Neither is there a proper time series of observations (of what?) to determine the denominator $(100 \%)$. Risk analysis is valuable, though methodologically not easy, but in view of the fuzziness of the concepts used, what remains is little more than open formula: words.

A closer look at the content and ambitions of the OCTA shows that it is of a very hybrid nature. On the one hand, it seems a threat assessment when it tries to make statements about organised crime groups and criminal markets. On the other hand, it carries elements of an impact assessment since the evaluation of the level of threat is sometimes directly connected to its impact on society. Moreover, the analysis of key facilitating factors (like the misuse of the road transport sector) contains elements of a broader vulnerability study.

\section{A reliable basis for policy making?}

There is very few public information and transparency about the methodology used for the OCTA. The open version of the reports contains hardly any indication about the approach and methods used. Even for scientific purposes, Europol and the Council seem to be reluctant to disclose anything about "the making of" the OCTA report (See [36]). However, heedful of the democratic foundation of knowledge the first author asked Europol to submit the basic instruments for closer methodological inspection. As a matter of fact, these concerned only the empty questionnaires sent to the 27 Member States. However, Europol followed the policy of "knowledge denied". Because these questionnaires had been sent to the Dutch police they had become Dutch documents and therefore were covered by the Dutch Freedom of Information Act. After a first refusal by the General Secretary of the ministry of Justice and an appeal to that decision, the Minister himself decided that the contested documents should be released. ${ }^{10}$

Close inspection of the questionnaires showed major defects. ${ }^{11}$ The most important points of critique concern the negligence of the methodological basic. In the first place, the validity of the instruments hinges on the validity of the definition of 'organised crime', as this is the construct which is supposed to be measured by the outcomes of the questionnaires. As mentioned above, the set of criteria ('Enfopol definition') intended to delineate 'organised crime' fails to act as a decision rule for selecting (and rejecting) cases to determine an 'organised crime set'. Consequently, whatever 'knowledge' is built on this basis has no validity, certainly when any kind of measurement or assessment is claimed to be derived from it.

The questionnaires of both OCTAs make a strange and amateurish impression. Moreover, they are different and therefore bound to produce incomparable

\footnotetext{
${ }^{10}$ The reader can download the questionnaire from www:cross-border-crime.net.

${ }^{11}$ For a more detailed discussion of these documents and the methodology of the OCTAs, see [17]).
} 
outcomes. Therefore, within two years we have two different threat assessments. Worse - apart from the fuzzy underlying definition - the wording of the questions is full of ambiguities, leaving ample space for the responding agency for various interpretations. Most of the questions are accompanied by explanatory notes, some of them increasing rather than decreasing the confusion. It does not help very much if the explanatory note explains that the question concerns a "subjective judgement" as the whole wording begs for it. The questionnaire of OCTA 2007 beats the lot when it comes to confusing 'clarifying' footnotes: more than 50, which the responsible officer has to process before understanding the question.

On top of this, there are no indications of a formulated procedure according to which the answers to these questionnaires are subsequently processed in the sense of made comparable and cast into the threat assessment mould. Unless Europol provides evidence to the contrary, the evaluation of the instrument used leads to the conclusion of an unreliable and invalid threat assessment. Europol's 'knowledge denied' policy is against this background significant and worrying.

This description of the attempted but defective OCTA methodology, as well as our knowledge of the 'pre-OCTA methodology' merely consisting of a variety of Member States' contributions of very diverse quality [62], must be complemented by the political filtering process. The OCTA, although an 'owned' Europol document now, still heavily relies on information provided by the Member States and is still 'negotiated' with them. Many of these Member States are not likely to be ready to deliver all information about threats [59]. Except for the new Member States in the course of designing their assessment systems, there are no signs that Member States are fundamentally changing their own reporting system because of OCTA. On the contrary, new types of agencies (e.g. the harm oriented Serious Organised Crime Agency (SOCA) in the UK-[33]) and organised crime (threat) assessments emerged in some Member States (Dutch National Threat Assessment- [36, German BKA-reports-[40].

In the end the reader is not presented the technical and neutral knowledge document resulting from a professional analysis, but a "European" report. This is subject to (political) negotiation acceptable to all Member States [59]. This has been described as an annual ritual dance with lots of smoke and shady procedures to decide on the "truth" about organised crime [58].

\section{Relevant and interesting content?}

Both open versions of the OCTA 2006 and 2007 reports mention a variety of threats. The content, terminology and structure of the 2007 report differs from this of 2006: inclusion of at chapter on "regions and hubs", no separate chapter on the "organised crime environment", no more explicit conclusions or executive summary, ...

According to the 2006 OCTA conclusions, the main threatening aspects of organised groups were, "first, the overwhelming obstacles in dismantling them because of their international dimension or influence, and second, their level of infiltration in society and economy" [27]. In that context, four main categories of groups were identified: (1) Principally territoriality based, indigenous OC groups but with extensive transnational activities; (2) ethnically homogeneous groups with their leadership and main assets abroad; (3) dynamic networks of perpetrators whose fluid 
organisational setup make them less susceptible to conventional investigative techniques; and (4) outlaw motorcycle gangs and other groups based on strictly defined organisational principles without an ethnic component. The OCTA 2007 does not make such explicit conclusions and only reports on the "most significant aspects" of "seven key areas of interest" (comparable to the "key indicators" of the 2006 report) and identifies three main categories of organised crime groups (compared to four in 2006): (1) Traditionally indigenous groups or EU-based groups; (2) Traditionally non-indigenous or non EU-based groups and (3) Intermediary situations including both second generation OC groups and traditionally indigenous groups that integrally exploit an international dimension for isolation and shielding of leaders or assets [28]. These categories of groups are considered threatening (first category), less threatening with a potential to grow (first category) or "most interesting" and "potentially more threatening" (fourth category). One may wonder how these 'second generation OC groups' were so suddenly detected.

With regard to the criminal markets, both the 2006 and 2007 report list six identical "horizontal" facilitating factors (document forgery and identity fraud, technology, the misuse of the road transport sector, the exploitation of the financial sector, globalisation and borders) presenting opportunities for organised crime groups. Contrary to the 2007 report and with only very implicit links to what is mentioned in the report itself, the OCTA 2006 formulated a general conclusion about this issue stating that the following markets should attract focused attention on the common EU level: drug trafficking, especially synthetic drugs, exploitation of trafficking in human beings and illegal immigration, fraud, Euro counterfeiting, commodity counterfeiting and intellectual property theft and money laundering [27]. The OCTA 2007 does not contain any statement in that respect.

Furthermore, the OCTA 2006 highlighted, again the following regional patterns: (1) South West Europe, in particular with regard to illegal immigration, cocaine and cannabis trafficking for further distribution in the EU; (2) South East Europe, specifically with regard to heroin trafficking, illegal immigration and trafficking in human beings, aimed at the whole of the EU; (3) North East Europe with regard to highly taxed products aimed at the Nordic countries and beyond; (4) Particular transportation hubs, such as harbours and airports pertaining to the Atlantic region, used for the movement of various commodities to and from the EU, in particular drugs [27]. In its new "Regions and Hubs" chapter, the 2007 report distinguishes between South-East, South-West, North-Western or Atlantic "regions" and NorthWest, South-West, North-East, Southern and seclusion "criminal hubs" and relate these to organised crime groups and criminal markets [28].

Although both OCTA's, and this for the first time at European level, contain elements of ranking and sometimes explicit statements about levels of threat (highest threat, most threatening), the reports can hardly be seen as a priority setting tool for policy makers. The 2007 report does not even provide for conclusions about what the report considers as the most threatening aspects. The reports suggest that Europe is threatened by all kinds of (mostly non-indigenous) criminal groups, committing many types of profit driven crimes, regionally spread across Europe. As such, OCTA does not look like a sharp priority setting tool. With some creativity, such conclusions may justify nearly any policy decision. Moreover, readers with some background in organised crime research (see e.g. [32]) will probably not be very 
surprised by the OCTA conclusions. Many of the trends and threats described have been reported elsewhere before [21].

OCTA and policy making

Studying the 'genesis' of 'knowledge based' policy making it would be insightful to follow the conversion of a purported knowledge document into the relevant policy. What can be observed in relation to the OCTAs? In June 2006 and May 2007, the Council of the European Union took conclusions, setting the EU priorities for the fight against organised crime based on the OCTA [14, 15]. In 2006, the Council only set general regional priorities combined with categories of organised crime groups (see above) and specific types of crime.

It is remarkable that the 2007 Council conclusions take up elements from the executive summary of the OCTA of the year before, not as such mentioned in the 2007 OCTA, about the international dimension and influence of criminal groups, as well as their level of infiltration into society (especially the misuse of legitimate business structures). Only a new statement on the misuse of technology is added. The 2007 conclusions then copy the list of criminal markets, again only mentioned in the 2006 OCTA (see above), and emphasise the importance of regionally based criminal hubs linking these hubs to criminal markets.

These conclusions and priorities relate to both OCTA reports, but not in a unilateral way. While the 2007 conclusions draw to an important extent from the OCTA from the year before, in addition it uses only very general elements of the 2007 OCTA. Moreover, the absence of a summary or conclusions in the 2007 OCTA makes it harder to ascertain to what extent the OCTA actually inspired the political decision making process.

Overall, however, the Council conclusions remain as general as the OCTA conclusions on which they are said to be based. Again, these conclusions allow for nearly 'any' kind of policy in regard to organised crime and could equally have been deduced from the study of open sources alone. In addition, compared with the stated intentions leading to the two OCTAs, they are far removed from the promised proactively and strategically 'looking forward'. The policy consequences of the adoption of the OCTA conclusions are therefore limited. Many different policy decisions remain open and no doors are closed.

\section{Conclusions: ritual policy making}

We opened this article by referring to the rational knowledge principle, the 'mental super-ego': contemporary organised crime policy making in Europe should be 'knowledge based'. Policy decisions and policies have to be targeted following a profound knowledge of the crime phenomenon provided in analytical future oriented reports that clearly define crime threats and allow for priority setting.

In this article we have argued that the European organised crime policy does not deserve the qualification "knowledge based": neither are the conditions for creating such a policy are fulfilled, nor are the results (analysis and quality of formulation) of a sufficient level.

First, it can be concluded that the basic instruments to inform policy makers about organised crime threats, the OCTAs, cannot be regarded as reliable and valid 
sources. They cannot even be considered as a verifiable source as the methodology is not accounted for. Fending off the request for insight, Europol followed a consistent 'knowledge denied' policy and tried to prevent the release of methodological documents: the empty questionnaires. ${ }^{12}$ When under the Freedom of Information Act the documents were finally released, they testified of an irreparably defective methodology. The wording of both questionnaires was highly ambiguous, bound to evoke incomparable as well as multi-interpretable outcomes. This entails that the reliability of data input from the Member States will be low and also difficult to compare. The method according to which the 27 multi-interpretable outcomes have subsequently been converted into the OCTAs is not documented either (or the relevant documents were not covered by the Freedom of Information Act). Small surprise that the threats, which are derived from this opaque information pool, remain general and vague. This finding contrasts sharply with the rational 'mental super-ego': knowledge is open, transparent and verifiable and not secretly protected behind closed doors suggesting that there are things that are "not to be known".

That brings us to another unfulfilled condition: the falsifiability of the OCTAs. There are no instruments to test or falsify the validity of the statements put forward by the OCTAs. Because of the general and broad wording of the propositions, they always contain a grain of truth, which reminds to one of the oracles of Delphi like: "Tomorrow a great kingdom will perish", which proved to be true too, irrespective of the outcome of the impending battle. The OCTAs produce similar always-truestatements. It is true that a criminal organisation which is hard to dismantle is a threat. But the contrary is also true, namely that a crime-market in which each dismantled organisation is followed by a new one is a threat too. Is that not the traditional complaint of the police: organised crime is like a Hydra, if you cut of one head, there always appears a new one?

Not all Member States seem to have been satisfied with the quality of the OCTAs: the Belgium delegation was disappointed while the Dutch rejected the 'knowledgedenied policy' of Europol. However, this did not produce a new 'knowledge document'.

Against these considerations, we have to return to our opening question: are these manifestations of 'knowledge based' policy making sincere or just displays of ritual dancing accompanied by socially and politically acceptable incantations? Our description and analysis point at a predominance of ritualism. This is not unique for the OCTA alone but can be observed from the onset of organised crime policy making, in which 'belief statements' exceed fact/observation based statements. The same applies to the difference between open formula phrases and precise analytical statements. The documents reveal some flirting associations with methodological approaches (threat assessments, vulnerability studies), empirical research and analytical models, (like PEST and SWOT) ${ }^{13}$, but after an initial citation no trace

\footnotetext{
${ }^{12}$ Europol appealed against the ministerial decision to release the documents, but later withdrew this appeal.

${ }^{13}$ Pest(el) stands for: Political, Economic, Social, Technological, Environmental and Legislative circumstances (see: [54]). SWOT is an acronym for: Strength, Weakness, Opportunity and Threats.
} 
of these notions or a proper reference is to be found in the OCTA 6 questionnaire or the presentation of the outcomes. This degrades such references to incantations too.

These incantations and ritual dances are not without consequences. First, they disguise that organised crime political decision making is actually not knowledge based at all. Decisions are made and budgets spent because this is what decision makers want to do, not what evidence shows them to do. Further, the secrecy and rituals hamper discussions about the reliability and solidity of instruments like OCTA and cover up substantial data collection problems and important flaws in the conceptual framework. Another concrete consequence concerns the huge EU-wide efforts these OCTAs require, while the outcomes are debatable and the use made of them by policy makers appear to be very meagre.

Many of the answers to these problems could have been made available if an open discussion about these issues were possible and admitted. However, policy makers and agencies engaged in the fight against organised crime seem to be reluctant to enter such a debate about how the best knowledge can be produced. Knowledge is indeed not their core business. They are primarily action oriented, either involved in investigations against offenders or engaged in political actions like legislation. However, the nature of the subject requires more than activism: the leading players of law enforcement and policy making should go beyond thieftaking and mending laws. So, to respond to this new demand they grasped the available and thus far common concepts. However, the content of each these concepts is not clarified and fuzzy, beginning with the organised crime concept and its definition. Consequently, what remained were words with a high political and social acceptability which turned into incantations.

This article makes a plea for open relations and a public (scientific) debate about all these issues. This may lead to some falsifications and the dismantlement of cherished notions, but in the end it may generate better understanding, clearer communications and more effective policy.

\section{References}

1. Austin, J. L. (1962). How to do things with words. Oxford: Oxford University Press.

2. Black, C., Vander Beken, T., Frans, B., \& Paternotte, M. (2001). Reporting on organised crime. A shift from explanation to description in the Belgian annual report on organised crime. AntwerpApeldoorn: Maklu.

3. Behr, H. G. (1985). Organisiertes Verbrechen. Düsseldorf: Econ Verlag.

4. Castle, A. (2008). Measuring the impact of law the enforcement on organized crime. Trends in Organized Crime. doi:10.1007/s12117-008-9030.

5. Charter, D. (2008). Secret report reveals massive MEP fraud. The Times, 26 February.

6. Council of the European Union (1997). 6204/2/97. ENFOPOL 35, Brussels, 21 April 1997.

7. Council of the European Union (1999). 8469/99. CRIMORG 55, Brussels, 19 May 1999.

8. Council of the European Union (2000). 14942/00. CRIMORG 173/ CATS 72, Brussels, 22 December 2000 .

9. Council of the European Union (2001). 7825/01. CRIMORG 34, Brussels, 20 March 2001.

10. Council of the European Union (2001). 14959/1/01. CRIMORG 133, Brussels, 10 December 2001.

11. Council of the European Union (2004). 16054/04. The Hague Programme for strengthening freedom, security and justice in the European Union, 13 December 2004.

12. Council of the European Union (2005). 9778/2/05. Council and commission action plan implementing The Hague Programme on strengthening freedom, security and justice in the European Union, 10 June 2005. 
13. Council of the European Union (2005). 10180/4/05. Council conclusions on intelligence-led policing and the development of ht Organised Crime Threat Assessment (OCTA), 3 October 2005.

14. Council of the European Union (2006). 10181/06. CRIMORG 94, Brussels, 6 June 2006.

15. Council of the European Union (2007). 7547/3. CRIMORG 57 ENFOPOL 50 ENFOCUSTOM 50, Brussels 15 May 2007.

16. Di Nicola, A., \& McCallister, A. (2006). Existing approaches of risk assessment. European Journal on Criminal Policy \& Research, 12, 179-187.

17. van Duyne, P. C. (s.d.). Searching the organised crime knowledge grail. Disorganised EU threat methodology (forthcoming)

18. van Duyne, P. C. (1995). Het spook en de dreiging van de georganiseerde misdaad. The Hague: SDU Uitgeverij.

19. van Duyne, P. C. (2003). Medieval thinking and organized crime economy. In E. Viano, J. Magallanes, \& L. Bridel (Eds.), International organized crime: myth, power and profit. Durham: Carolina Academic.

20. van Duyne, P. C. (2004). The creation of a threat image: media, policy making and organised crime. In P. C. van Duyne, M. Jager, K. von Lampe, \& J. L. Newell (Eds.), Threats and phantoms of organised crime, corruption and terrorism (pp. 21-51). Nijmegen: Wolf Legal.

21. van Duyne, P. C. (2007). OCTA 2006: the unfulfilled promise. Trends in Organised Crime, 10, 120128.

22. van Duyne, P. C., Kouwenberg, R., \& Romeijn, G. (1990). Misdaadondernemingen. Ondernemende misdadigers in Nederland. Arnhem: Gouda-Quint.

23. van Duyne, P. C., \& Levi, M. (2005). Drugs and money. Managing the drug trade and crime-money in Europe. London: Routledge.

24. European Commission (2005). Communication from the commission to the council and the European Parliament. COM (2005)232 final. Developing a strategic concept on tackling organised crime. 2 June 2005.

25. European Commission (2005). Communication from the Commission to the Council and the European parliament. The Hague Programme: 10 priorities for the next five years. The partnership for European renewal in the field of freedom, security and justice. OJC 236. 24 September 2005.

26. European Monitoring Centre for Drugs and Drugs Addiction. (2006). Statistical Bulletin.

27. Europol (2006). OCTA. EU Organised Crime Assessment 2006. Available at http://register.consilium. europa.eu/pdf/en/06/st10/st10143.en06.pdf. Accessed 11 September 2008.

28. Europol (2007). OCTA. EU Organised Crime Threat Assessment 2007. Available at http://www.europol. europa.eu/publications/European_Organised_Crime_Threat_Assessment_(OCTA)/OCTA2007.pdf. Accessed 11 September 2008.

29. Fijnaut, C. (1985). Georganiseerde misdaad. Een onderzoek gerichte terreinverkenning. Justitiële Verkenningen, 9, 5-42.

30. Fijnaut, C., Bovenkerk, F., Bruinsma, G. J. N., \& van de Bunt, H. G. (1996). Eindrapport georganiseerde criminaliteit in Nederland. Bijlage VII, Inzake Opsporing. Enquêtecommissie Opsporingsmethoden. The Hague: SDU Uitgevers.

31. Fijnaut, C. and Jacobs, J. (Eds.) (1991). Organized crime and its containment: a transatlantic initiative, Deventer: Kluwer.

32. Fijnaut, C., \& Paoli, L., Eds. (2005). Organised crime in Europe. Concepts, patterns and control policies in the European Union and beyond. Dordrecht: Springer.

33. Harfield, C. (2006). SOCA. A paradigm shift in British policing. British Journal of Criminology, 46, $743-761$.

34. Home Affairs Committee (1994). Organised Crime. Minutes of evidence and memoranda. London, 16 November 1994.

35. Kinzig, J., \& Luczak, A. (2005). Organised crime in Germany: a passé-partout definition encompassing different phenomena. In C. Fijnaut, \& L. Paoli (Eds.), Organised crime in Europe. Concepts, patterns and control policies in the European Union and beyond (pp. 333-356). Dordrecht: Springer.

36. Klerks, P. (2007). Methodological aspects of the Dutch National Threat Assessment. Trends in Organised Crime, 10, 91-101.

37. Küster, D. (1991). Das Lagebild der organisierten Kriminalität in der Bundesrepublik Deutschland, illustriert anhand typischer Ermittlungsverfahren. In Organisierte Kriminalität in einem Europa durchlässiger Grenzen. Wiesbaden: Bundeskriminalamt.

38. von Lampe, K. (1995). Der lange Abschied vom Mafia-Paradigma. Neue Veröffentlichungen der organized-crime-Forschung. Kriminologisches Journal, 27(4), 298-302. 
39. von Lampe, K. (1999). Organized crime: Begriff und Theorie organisierter Kriminalität in den USA. Frankfurt am Main: Lang.

40. von Lampe, K. (2001). Not a process of enlightenment: the conceptual history of organized crime in Germany and the United States of America. Forum on Crime and Society, 2, 99-116.

41. von Lampe, K. (2005). Making the second step before the first: assessing organized crime. Crime, Law \& Social Change, 42, 227-259.

42. Levi, M. and Reuter, P. (2006). Money-laundering. The University of Chicago. http://www.publicpolicy. umd.edu/faculty/reuter/Working\%20Papers/Levi and Reuter.pdf. Accessed 11 September 2008.

43. Luczak, A. (2002). Mafiakraken. Die Konstruktion “organisierte Kriminalität”. Forum Recht Online, 2. http://www.forum-recht-online.de/2002/202/202luczak.htm. Accessed 11 September 2008.

44. Mack, J., \& Kerner, H. -J. (1975). The crime industry. Westmead: Saxon House.

45. McIntosh, M. (1975). The organisation of crime. London: The Macmillan.

46. Middelburg, B. (1988). De mafia in Amsterdam. Amsterdam: De Arbeiderspers.

47. National Criminal Intelligence Service (1993). Briefing paper. An outline assessment of the threat and impact by organised/enterprise crime upon United Kingdom interests. London: NCIS.

48. National Criminal Intelligence Service (1993). Organised crime conference: A threat assessment; a summary of speeches presented at the Police Staff College, Hampshire, 24th-26th May. United Kingdom: OICJ.

49. Paoli, L., Güller, N., \& Palidda, S. (2000). Pilot report to describe and analyse local drug markets. First phase final report: illegal drug markets in Frankfurt and Milan. Lisbon: EMCDDA.

50. Parlementaire Enquêtecommissie Opsporingsmethoden (1996). Inzake Opsporing. The Hague: Sdu Uitgevers.

51. Quirke, B. (2008). EU fraud and new member states. The case of the Czech Republic. In P. C. van Duyne, J. Harvey, A. Maljevic, K. von Lampe, \& M. Scheinost (Eds.), European crime markets at cross-roads. Extended and extending criminal Europe (pp. 229-244). Nijmegen: Wolf Legal.

52. Rebscher, E., \& Vahlenkamp, W. (1988). Organisierte Kriminalität in der Bundesrepublik Deutschland: Bestandsaufnahme, Entwicklungstendenzen und Bekämpfung aus der Sicht der Polizeipraxis. Wiesbaden: Bundeskriminalamt.

53. Shore, C. (2003). Corruption scandals in America and Europe. Enron and EU fraud in comparative perspective. Social Analysis, 47(3), 147-153.

54. Sieber, U., \& Bögel, M. (1993). Logistik der organisieren Kriminalität. Wiesbadem: BKAForschungsreihe.

55. Strang, S. (s.d.). Project SLEIPNIR: An analytical technique for operational priority setting. Royal Canadian Mounted Police. https://analysis.mitre.org/proceedings/Final_Papers_Files/135_Camera_ Ready_Paper.pdf. Accessed 11 September 2008.

56. Vander Beken, T. (2004). Risky business: a risk based methodology to measure organized crime. Crime, Law \& Social Change, 41, 471-516.

57. Vander Beken, T., Ed. (2005). Organised crime and vulnerability of economic sectors. AntwerpApeldoorn: Maklu.

58. Vander Beken, T. (2005). Beeldvorming en beleid rond georganiseerde criminaliteit in de Europese Unie: indien niet ernstig, gelieve zich te onthouden. Panopticon. Tijdschrift voor Strafrecht, Criminologie \& Forensisch Welzijnswerk, 27, 30-46.

59. Vander Beken, T., Savona, E., Korsell, L., Defruytier, M., Di Nicola, A., Heber, A., et al. (2005). Measuring organised crime in Europe. A feasibility study of a risk based methodology across the European Union. Antwerp-Apeldoorn: Maklu.

60. Van Swaaningen, R. (2005). Public safety and the management of fear. Theoretical Criminology, 9(3), 289-305.

61. Verpoest, K., \& Vander Beken, T. (2005). The European Union methodology for reporting on organised crime. Available at: http://assessingorganisedcrime.net/. Accessed 11 September 2008.

62. Vettori, B. (2006). Comparing data sources on organised crime across the EU. A first step towards an EU statistical apparatus. In P. C. van Duyne, A. Maljevic, M. van Dijck, K. von Lampe, \& J. L. Newell (Eds.), The organisation of crime-for-profit. Conduct, law and measurement (pp. 43-67). Nijmegen: Wolf Legal.

63. Weschke, E., \& Heine-Heiß, K. (1990). Organisierte Kriminalität als Netzstrukturkriminalität. Berlin: Fachhochschule für Verwaltung und Rechtspflege. 